\title{
Cimetidine enhances the plasma praziquantel concentration and treatment efficacy against Microcotyle sebastis in cultured rockfish Sebastes schlegeli
}

\author{
Ki Hong Kim*, Chun Soo Kim \\ ${ }^{1}$ Department of Aquatic Life Medicine, College of Fisheries Science, Pukyong National University, Pusan 608-737, Korea
}

\begin{abstract}
The effect of cimetidine on the praziquantel concentration in the blood of the rockfish Sebastes schlegeli and the consequent effect on the treatment efficacy against Microcotyle sebastis were investigated. Fish were divided into 7 groups and orally administered praziquantel alone (200 and $100 \mathrm{mg} \mathrm{kg}^{-1}$ body weight [BW]) or in combination with cimetidine (in doses of 200, 100 or $50 \mathrm{mg} \mathrm{kg}^{-1} \mathrm{BW}$ cimetidine with a praziquantel dose of $100 \mathrm{mg} \mathrm{kg}^{-1} \mathrm{BW}$ ). The fish in the sixth group were coadministered $50 \mathrm{mg}$ praziquantel and $200 \mathrm{mg}$ cimetidine $\mathrm{kg}^{-1} \mathrm{BW}$. The fish in the control group were administered only saline. At $24 \mathrm{~h}$ post-treatment, the plasma was analyzed for praziquantel by reversed-phase high-performance liquid chromatography (RP-HPLC) using diazepam as the internal standard, and the gills were examined to confirm the effectiveness of each treatment. The praziquantel concentration in plasma of fish administered $100 \mathrm{mg}$ praziquantel $+200 \mathrm{mg}$ cimetidine $\mathrm{kg}^{-1} \mathrm{BW}$ was not significantly different from that of fish treated with $200 \mathrm{mg}$ praziquantel $\mathrm{kg}^{-1}$ BW and was significantly ( $<0.05$ ) higher (about 2 times) than that of fish administered $100 \mathrm{mg}$ praziquantel kg-1 BW. The group of fish administered $50 \mathrm{mg}$ praziquantel $+200 \mathrm{mg}$ cimetidine $\mathrm{kg}^{-1}$ BW showed a similar plasma praziquantel concentration to that in the fish treated with $100 \mathrm{mg}$ praziquantel $\mathrm{kg}^{-1} \mathrm{BW}$. The treatment efficacies of the groups of fish coadministered $100 \mathrm{mg}$ praziquantel $\mathrm{kg}^{-1} \mathrm{BW}$ and various concentrations of cimetidine $\left(200,100\right.$ and $50 \mathrm{mg} \mathrm{kg}^{-1} \mathrm{BW}$ ) were not significantly different from that of the group of fish administered $200 \mathrm{mg}$ praziquantel $\mathrm{kg}^{-1} \mathrm{BW}$, but were significantly higher than those of the groups of fish fed $100 \mathrm{mg}$ praziquantel $\mathrm{kg}^{-1} \mathrm{BW}$ alone or coadministered $50 \mathrm{mg}$ praziquantel $+200 \mathrm{mg}$ cimetidine $\mathrm{kg}^{-1} \mathrm{BW}$.
\end{abstract}

KEY WORDS: Cimetidine $\cdot$ Praziquantel $\cdot$ RP-HPLC $\cdot$ Microcotyle sebastis $\cdot$ Rockfish

\section{INTRODUCTION}

Cimetidine is a histamine $\mathrm{H}_{2}$ receptor antagonist and has been shown to differentially inhibit a variety of $\mathrm{P}_{450}$ isoforms (Knodell et al. 1991). Administration of cimetidine has been reported to result in clinically significant pharmacokinetic interactions with a variety of drugs, including praziquantel (Dachman et al. 1994,

*E-mail: khkim@pknu.ac.kr
Ebeid et al. 1994, Metwally et al. 1995, Jung et al. 1997). Recently, Kim et al. (1998) and Kim \& Cho (2000) reported that oral administration of praziquantel was effective in treating Microcotyle sebastis infestations in cultured rockfish Sebastes schlegeli.

Although Kim et al. (2001a) have reported that coadministration of cimetidine with praziquantel led to a significantly increased treatment efficacy of the latter drug against Microcotyle sebastis, there are no experimental data on the pharmacokinetic interactions between praziquantel and cimetidine in fish. Therefore, 


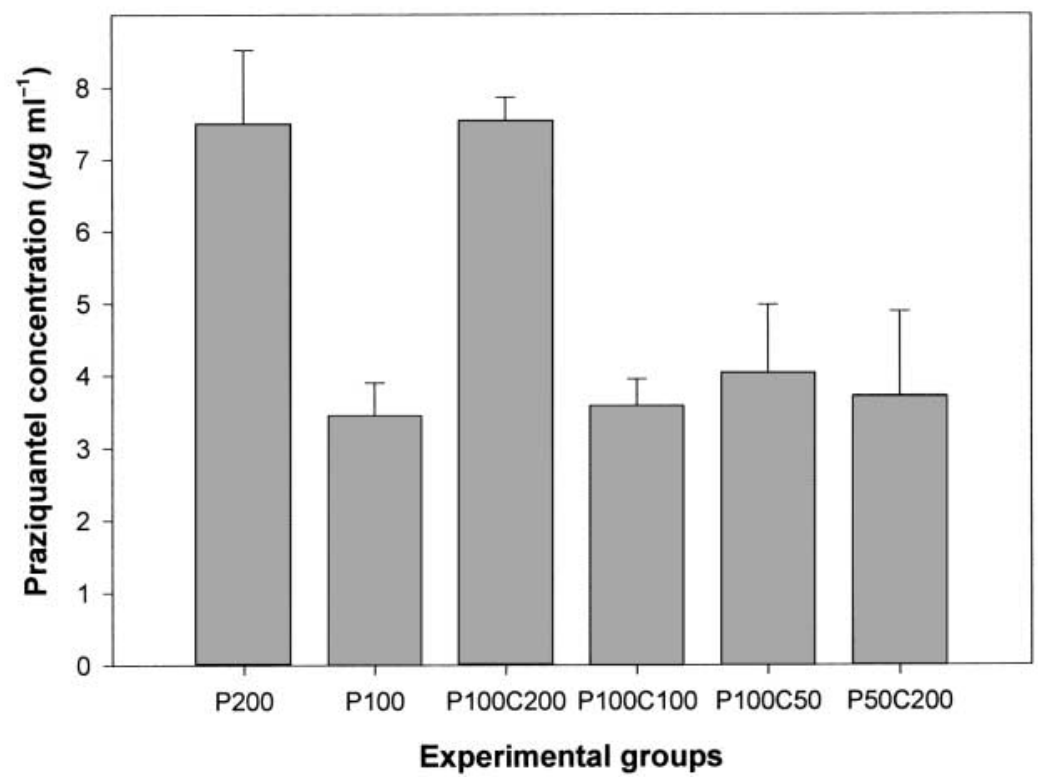

Fig. 1. Plasma concentrations (mean \pm standard error) of praziquantel (P) in rockfish Sebastes schlegeli $24 \mathrm{~h}$ after oral administration of $\mathrm{P}\left(\mathrm{mg} \mathrm{kg}^{-1}\right.$ BW) alone or coadministered with cimetidine $\left(\mathrm{C}, \mathrm{mg} \mathrm{kg}^{-1} \mathrm{BW}\right)$ in various combinations

the present study was undertaken to examine the effect of cimetidine on the praziquantel concentration in the blood of rockfish and the consequent effect on the treatment efficacy against $M$. sebastis.

\section{MATERIALS AND METHODS}

Fish. Netpen-reared juvenile rockfish Sebastes schlegeli (average body weight [BW] $110 \mathrm{~g}$ ) were obtained from a local rockfish farm in Tongyoung, Korea. The presence of Microcotyle sebastis on the gills was confirmed by examination of 5 fish. After a week's acclimation, 35 fish were randomly divided into 7 groups of 5 fish in each group. The volume of each experimental aquarium was 501 , the water temperature was $20 \pm 1^{\circ} \mathrm{C}$, and the salinity was $33 \%$. Fish were not fed throughout the experiment.
Treatment regimen. Fish were anesthetized with MS222 (Sigma) and were intubated directly into the stomach for the administration of varying concentrations of praziquantel and cimetidine. The groups were administered as follows: the first group was fed $200 \mathrm{mg}$ praziquantel (Shinpoong Pharmaceutical) $\mathrm{kg}^{-1} \mathrm{BW}$; the second group $100 \mathrm{mg}$ praziquantel $\mathrm{kg}^{-1}$ BW; the third group was coadministered $100 \mathrm{mg}$ praziquantel $+200 \mathrm{mg}$ cimetidine $\mathrm{kg}^{-1} \mathrm{BW}$; the fourth group $100 \mathrm{mg}$ praziquantel $+100 \mathrm{mg}$ cimetidine $\mathrm{kg}^{-1} \mathrm{BW}$; the fifth group $100 \mathrm{mg}$ praziquantel $+50 \mathrm{mg}$ cimetidine $\mathrm{kg}^{-1} \mathrm{BW}$; and the sixth group $50 \mathrm{mg}$ praziquantel $+200 \mathrm{mg}$ cimetidine $\mathrm{kg}^{-1}$ BW. The fish in the seventh group (control group) were given $0.7 \%$ saline. At $24 \mathrm{~h}$ post-treatment, all fish in each group were sampled and anaesthetized with MS222. Blood samples drawn from the caudal vein were centrifuged immediately to get plasma samples and were kept frozen at $-70^{\circ} \mathrm{C}$ until analyzed. The gills of fish in each group were examined to confirm the effectiveness of each treatment.

Chromatographic conditions. The chromatographic analysis was performed according to the method established previously in this laboratory (Kim et al. 2001b). The instruments used were a Hewlett-Packard (HP 1100 Series) high-performance liquid chromatograph equipped with QUAT pump (HP1100 Series G1311A), an automatic gradient controller (HP1100 Series G1324A), an injection valve fitted with a $5 \mathrm{ml}$ sampling loop, a variable-wavelength UV detector and a data module. Analysis was performed on an ODS2 C18 column $(125 \times 4 \mathrm{~mm}$, Hewlett-Packard) with acetonitrile-water (45:55, v/v) as the mobile phase. The column was kept at room temperature (20 to $24^{\circ} \mathrm{C}$ ) and the flow rate was kept constant

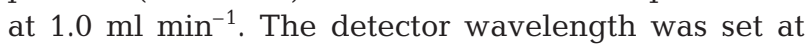
$217 \mathrm{~nm}$. Between each $200 \mu \mathrm{l}$ injection the column was washed for 15 min with $100 \%$ acetonitrile.

Preparation of plasma. To a $1.0 \mathrm{ml}$ volume of plasma, $1.0 \mathrm{ml}$ of $100 \%$ acetonitrile and $0.4 \mathrm{ml}$ of the inter-

Table 1. Significance in plasma praziquantel concentrations between experimental groups calculated using Student's $t$-test $24 \mathrm{~h}$ after oral administrations. C: cimetidine $\left(\mathrm{mg} \mathrm{kg}^{-1} \mathrm{BW}\right)$; P: praziquantel $\left(\mathrm{mg} \mathrm{kg}^{-1} \mathrm{BW}\right)$

\begin{tabular}{|c|c|c|c|c|c|c|}
\hline Group & P200 & P100 & $\mathrm{P} 100+\mathrm{C} 200$ & $\mathrm{P} 100+\mathrm{C} 100$ & $\mathrm{P} 100+\mathrm{C} 50$ & $\mathrm{P} 50+\mathrm{C} 200$ \\
\hline P200 & - & 0.022 & 0.969 & 0.062 & 0.067 & 0.071 \\
\hline P100 & & - & 0.002 & 0.848 & 0.609 & 0.838 \\
\hline $\mathrm{P} 100+\mathrm{C} 200$ & & & - & 0.004 & 0.025 & 0.034 \\
\hline$P 200+C 100$ & & & & - & 0.745 & 0.934 \\
\hline P100 + C50 & & & & & - & 0.846 \\
\hline
\end{tabular}


nal standard solution were added. The sample was allowed to stand for $10 \mathrm{~min}$ at $4^{\circ} \mathrm{C}$, then centrifuged at $10000 \times g$ for $10 \mathrm{~min}$. The collected supernatant was evaporated to dryness with a speed vacuum (HetoHolten A/S). The dry residue was dissolved in $1 \mathrm{ml}$ of mobile phase, and a portion of $200 \mu \mathrm{l}$ was injected into the high-performance liquid chromatography (HPLC) column.

Statistical analysis. The plasma praziquantel concentrations were analyzed using Student's $t$-test, and the abundances of Microcotyle sebastis were analyzed using the Mann-Whitney $U$-test.

\section{RESULTS}

\section{Praziquantel concentrations in plasma}

After $24 \mathrm{~h}$ of each treatment, the praziquantel concentration in plasma of fish administered $100 \mathrm{mg}$ praziquantel $+200 \mathrm{mg}$ cimetidine $\mathrm{kg}^{-1} \mathrm{BW}$ was not significantly different from that of fish treated with $200 \mathrm{mg}$ praziquantel $\mathrm{kg}^{-1} \mathrm{BW}$ and was significantly $(\mathrm{p}<0.05)$ higher (ca. $2 \times$ ) than that of fish administered $100 \mathrm{mg}$ praziquantel $\mathrm{kg}^{-1} \mathrm{BW}$ (Figs. 1 \& 2, Table 1). Although the fish administered $100 \mathrm{mg}$ praziquantel $+100 \mathrm{mg}$ cimetidine $\mathrm{kg}^{-1} \mathrm{BW}$ or $100 \mathrm{mg}$ praziquantel $+50 \mathrm{mg}$ cimetidine $\mathrm{kg}^{-1}$ BW showed slightly higher plasma praziquantel concentrations than fish administered $100 \mathrm{mg}$ praziquantel $\mathrm{kg}^{-1} \mathrm{BW}$, there were no statistical significances. However, the group of fish administered $50 \mathrm{mg}$ praziquantel $+200 \mathrm{mg}$ cimetidine $\mathrm{kg}^{-1} \mathrm{BW}$ showed similar plasma praziquantel concentration to the fish treated with $100 \mathrm{mg}$ praziquantel $\mathrm{kg}^{-1} \mathrm{BW}$. No praziquantel was detected in the plasma of control fish.

\section{Treatment efficacy}

All the groups of fish administered praziquantel alone or coadministered praziquantel and cimetidine simultaneously showed significantly lower abundances of Microcotyle sebastis on the gills than the control
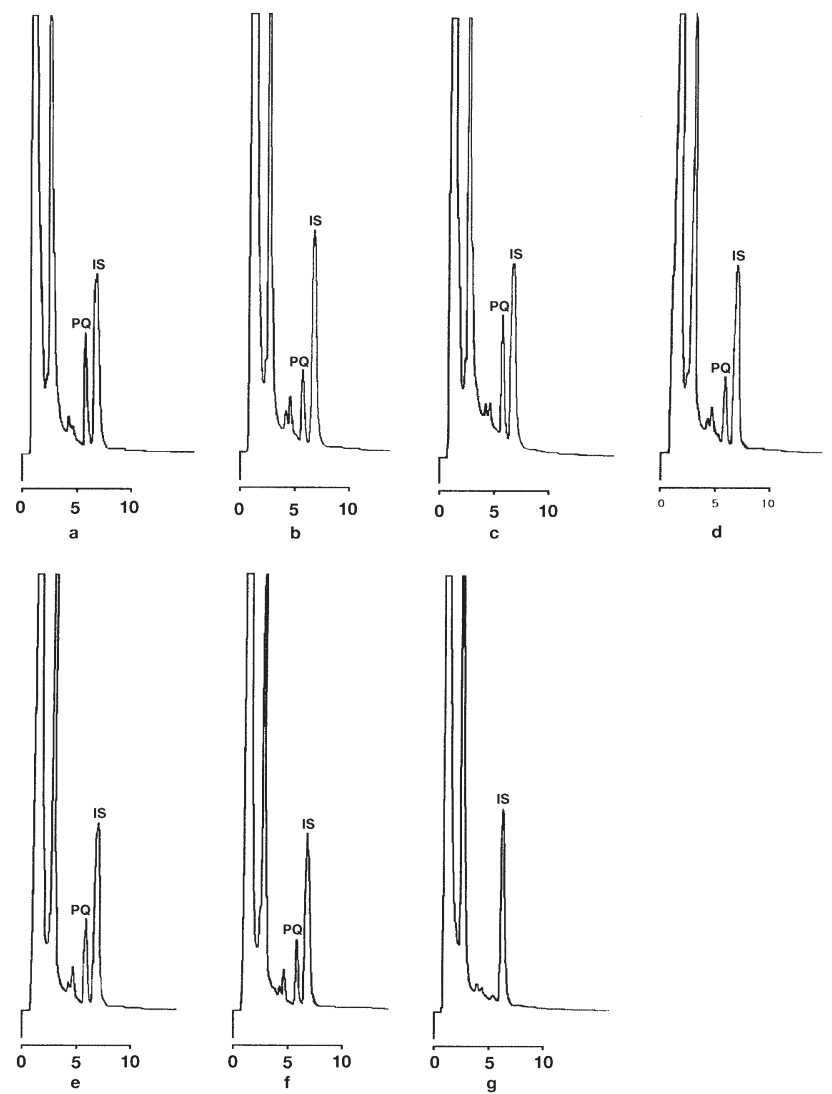

Fig. 2. Chromatograms of praziquantel (PQ) in plasma of rockfish compared with diazepam as an internal standard (IS) $24 \mathrm{~h}$ after each oral treatment with (a) $200 \mathrm{mg}$ praziquantel $\mathrm{kg}^{-1} \mathrm{BW}$, (b) $100 \mathrm{mg}$ praziquantel $\mathrm{kg}^{-1} \mathrm{BW}$, (c) $100 \mathrm{mg}$ praziquantel $+200 \mathrm{mg}$ cimetidine $\mathrm{kg}^{-1} \mathrm{BW}$, (d) $100 \mathrm{mg}$ praziquantel $+100 \mathrm{mg}$ cimetidine $\mathrm{kg}^{-1} \mathrm{BW}$, (e) $100 \mathrm{mg}$ praziquantel + $50 \mathrm{mg}$ cimetidine $\mathrm{kg}^{-1} \mathrm{BW}$ and (f) $50 \mathrm{mg}$ praziquantel + $200 \mathrm{mg}$ cimetidine $\mathrm{kg}^{-1} \mathrm{BW}$ and $(\mathrm{g})$ with control

fish (Fig. 3, Table 2). The treatment efficacies of the groups of fish coadministered $100 \mathrm{mg}$ praziquantel $\mathrm{kg}^{-1} \mathrm{BW}$ and various concentrations of cimetidine (200, 100 and $50 \mathrm{mg} \mathrm{kg}^{-1} \mathrm{BW}$ ) were not significantly different from those of the group of fish administered $200 \mathrm{mg}$ praziquantel $\mathrm{kg}^{-1}$ BW but were significantly

Table 2. Significance in abundance of Microcotyle sebastis between experimental groups calculated using Mann-Whitney $U$-test $24 \mathrm{~h}$ after oral administrations. C: cimetidine $\left(\mathrm{mg} \mathrm{kg}^{-1} \mathrm{BW}\right)$; P: praziquantel $\left(\mathrm{mg} \mathrm{kg}^{-1} \mathrm{BW}\right)$

\begin{tabular}{|c|c|c|c|c|c|c|c|}
\hline Group & Control (saline) & P200 & P100 & $\mathrm{P} 100+\mathrm{C} 200$ & $\mathrm{P} 100+\mathrm{C} 100$ & $\mathrm{P} 100+\mathrm{C} 50$ & $\mathrm{P} 50+\mathrm{C} 200$ \\
\hline Control & - & 0.000 & 0.000 & 0.000 & 0.000 & 0.000 & 0.000 \\
\hline P200 & & - & 0.020 & 0.346 & 0.791 & 0.143 & 0.111 \\
\hline P100 & & & - & 0.026 & 0.020 & 0.029 & 0.707 \\
\hline $\mathrm{P} 100+\mathrm{C} 200$ & & & & - & 0.387 & 0.550 & 0.138 \\
\hline $\mathrm{P} 100+\mathrm{C} 100$ & & & & & - & 0.121 & 0.116 \\
\hline P100 + C50 & & & & & & - & 0.153 \\
\hline
\end{tabular}




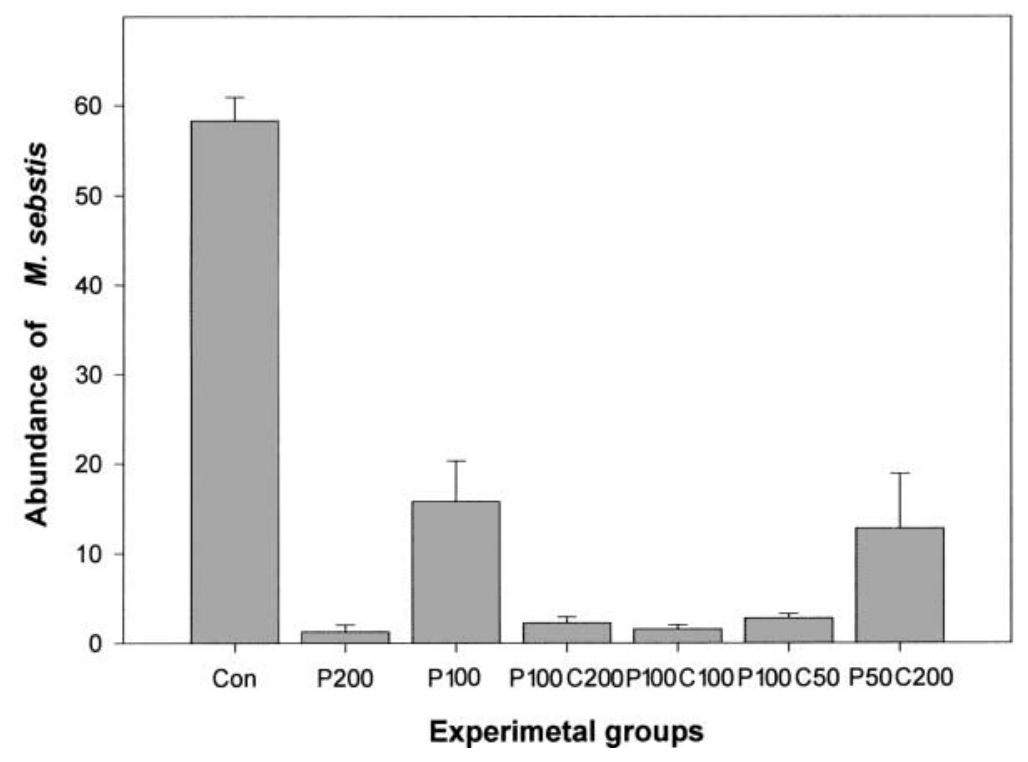

Fig. 3. Abundance (mean \pm SE) of Microcotyle sebastis on the gills of rockfish Sebastes schlegeli $24 \mathrm{~h}$ after oral administration of praziquantel $\left(\mathrm{P}_{;} \mathrm{mg} \mathrm{kg}^{-1}\right.$ BW) alone or coadministered with cimetidine $\left(C_{i} \mathrm{mg} \mathrm{kg}^{-1} \mathrm{BW}\right)$ in various combinations

studies (Overbosch 1992, Dachman et al. 1994, Jung et al. 1997, Sotelo \& Jung 1998, Al-Khodairy et al. 1999).

The present results showed that coadministration of $200 \mathrm{mg}$ cimetidine $\mathrm{kg}^{-1}$ BW with 100 or $50 \mathrm{mg}$ praziquantel $\mathrm{kg}^{-1}$ BW raised the plasma praziquantel level to that achieved by administration of praziquantel alone at dosages of 200 or $100 \mathrm{mg} \mathrm{kg}^{-1} \mathrm{BW}$, respectively. Although addition of $100 \mathrm{mg}$ cimetidine or $50 \mathrm{mg}$ $\mathrm{kg}^{-1} \mathrm{BW}$ to $100 \mathrm{mg}$ praziquantel $\mathrm{kg}^{-1} \mathrm{BW}$ did not significantly affect the plasma praziquantel levels $24 \mathrm{~h}$ post-administration when compared with oral administration of $100 \mathrm{mg}$ praziquantel $\mathrm{kg}^{-1} \mathrm{BW}$ alone, the treatment efficacies against Microcotyle sebastis were not significantly different from those of the group coadministered $100 \mathrm{mg}$ praziquantel + $200 \mathrm{mg}$ cimetidine $\mathrm{kg}^{-1} \mathrm{BW}$. In mammals, cimetidine is rapidly absorbed following oral administration, peak plasma levels being attained after approximately $2 \mathrm{~h}$ when taken with food, or after $1 \mathrm{~h}$ when

higher than those of the groups of fish fed $100 \mathrm{mg}$ praziquantel $\mathrm{kg}^{-1} \mathrm{BW}$ alone. Because of large variations in treatment efficacy in the fish coadministered $50 \mathrm{mg}$ praziquantel $+200 \mathrm{mg}$ cimetidine $\mathrm{kg}^{-1} \mathrm{BW}$, there were no significant differences between this group and other experimental groups except the control group.

\section{DISCUSSION}

The results of the present study agree with a previous report which indicated that coadministration of cimetidine with praziquantel led to a significantly increased treatment efficacy of the latter drug against Microcotyle sebastis infestation in rockfish Sebastes schlegeli (Kim et al. 2001a). Moreover, in the present study we first demonstrated in fish that these increased treatment efficacies by cimetidine supplementation were through elevation of praziquantel concentration in the blood of treated fish. Masimirembwa \& Hasler (1994) reported that praziquantel was metabolized by phenobarbitone-inducible isoforms of cytochrome $\mathrm{P}_{450}$, and cimetidine was an effective inhibitor of the metabolism of praziquantel. Diekmann et al. (1989) also reported that cimetidine was an effective inhibitor of praziquantel metabolism at a dose of $200 \mathrm{mg} \mathrm{kg}^{-1} \mathrm{BW}$ in rats. In the treatment of human neurocysticercosis, increase of praziquantel's bioavailability by coadministration of cimetidine and consequently increase of treatment efficacy were well demonstrated by many taken without food, and about two-thirds of the oral dose is excreted within $24 \mathrm{~h}$ (Kelly et al. 1995). According to the pharmacokinetic study of Kim et al. (2001b), praziquantel was also sharply decreased in plasma of rockfish after $24 \mathrm{~h}$ of oral administration. Therefore, the results of the present study suggest that oral administration of cimetidine at doses of 100 or $50 \mathrm{mg}$ $\mathrm{kg}^{-1} \mathrm{BW}$ to rockfish can inhibit praziquantel metabolism in liver and can raise plasma praziquantel levels enough to kill M. sebastis within $24 \mathrm{~h}$.

Acknowledgements. This study was supported by a grant from the Dae Sung Microbiological Labs Co., and a grant from the Ministry of Maritime Affairs and Fisheries, Republic of Korea.

\section{LITERATURE CITED}

Al-Khodairy AT, Annoni JM, Uebelhart D (1999) Parenchymatous cerebral neurocysticercosis in a quadriplegic patient. Spinal Cord 37:142-146

Dachman WD, Adubofour KO, Bikin DS, Johnson CH, Mullin PD, Winograd M (1994) Cimetidine-induced rise in praziquantel levels in a patient with neurocysticercosis being treated with anticonvulsants. J Infect Dis 169:689-691

Diekmann HW, Schneidereit M, Overbosch D (1989) Inhibitory effects of cimetidine, ketoconazole and miconazole on the metabolism of praziquantel. Acta Leiden 57: $217-228$

Ebeid FA, Metwally A, Botros SS, Bennett JL (1994) Treatment of experimental schistosomiasis mansoni with praziquantel alone and combined with cimetidine. Arznei- 
mittelforschung 44:1268-1270

Jung H, Medina R, Castro N, Corona T, Sotelo J (1997) Pharmacokinetic study of praziquantel administered alone and in combination with cimetidine in a single-day therapeutic regimen. Antimicrob Agents Chemother 41:1256-1259

Kelly MT, McGuirk D, Bloomfield FJ (1995) Determination of cimetidine in human plasma by high-performance liquid chromatography following liquid-liquid extraction. J Chromatogr 668:117-123

Kim KH, Cho JB (2000) Treatment of Microcotyle sebastis (Monogenea: Polyopisthocotylea) infestation with praziquantel in an experimental cage simulating commercial rockfish Sebastes schlegeli culture conditions. Dis Aquat Org 40:229-231

Kim KH, Park SI, Jee BY (1998) Efficacy of oral administration of praziquantel and mebendazole against Microcotyle sebastis (Monogenea) infestation of cultured rockfish (Sebastes schlegeli). Fish Pathol 33:467-471

Kim KH, Lee EH, Kwon SR, Cho JB (2001a) Treatment of Microcotyle sebastis infestation in cultured rockfish Sebastes schlegeli by oral administration of praziquantel in combination with cimetidine. Dis Aquat Org 44:133-136

Editorial responsibility: Jo-Ann Leong,

Corvallis, Oregon, USA
Kim KH, Kim CS, Kim JW (2001b) Depletion of praziquantel in plasma and muscle tissue of cultured rockfish Sebastes schlegeli after oral and bath treatment. Dis Aquat Org 45: 203-207

Knodell R, Browne D, Gwozdz G, Brian W, Guengerich F (1991) Differential inhibition of individual human liver cytochrome P-450 by cimetidine. Gastroenterology 101: 1680-1691

Masimirembwa CM, Hasler JA (1994) Characterisation of praziquantel metabolism by rat liver microsomes using cytochrome P450 inhibitors. Biochem Pharmacol 48: 1779-1783

Metwally A, Bennett JL, Botros S, Ebeid F (1995) Effect of cimetidine, bicarbonate and glucose on the bioavailability of different formulations of praziquantel. Arzneimittelforschung 45:516-518

Overbosch D (1992) Neurocysticercosis. An introduction with special emphasis on new developments in pharmacotherapy. Schweiz Med Wochenschr 122:893-898

Sotelo J, Jung H (1998) Pharmacokinetic optimisation of the treatment of neurocysticercosis. Clin Pharmacokinet 34: $503-515$

Submitted: July 24, 2001; Accepted: September 25, 2001 Proofs received from author(s): April 16, 2002 